\title{
Physical and antioxidant properties of two Algerian date fruit species (Phoenix dactylifera L. and Phoenix canariensis $\mathrm{L}$.)
}

\author{
Amrane Djouab ${ }^{1,2 *}$, Salem Benamara', Hassina Gougam1, Hayet Amellal ${ }^{3}$, Karima Hidous ${ }^{1}$ \\ ${ }^{1}$ Laboratoire de Recherche Technologie Alimentaire, Faculté des Sciences de I'Ingénieur, Université M'hamed Bougara, Boumerdès \\ 35000, Algérie, ${ }^{2}$ Centre de Recherche Scientifique et Technique en Analyses Physico-chimiques (CRAPC), BP 248, Alger 16004, Algérie, \\ ${ }^{3}$ Département de Biologie, Faculté des Sciences, Université M'hamed Bougara, Boumerdès 35000, Algérie
}

\section{A B S T R A C T}

\begin{abstract}
The present comparative study aimed to investigate for the first time some physical and antioxidant properties of date fruits from Phoenix dactylifera L. (cv. Mech-Degla) (MD) and Phoenix canariensis L. (CRD) palms. The physical properties of whole date fruits and date fruit seeds were analyzed separately. But the antioxidant potential (AP), evaluated throughout total phenolic content (TPC), reducing power (RP) and antiradicalar activity (AA) towards the stable free radical 2,2-Diphenyl-1-picrylhydrazyl (DPPH) were analyzed in different tissues of date fruit fleshes. Results showed that linear dimensions, equivalent diameter, volume, mass, sphericity, surface area, bulk density, porosity, angle of repose and hardness, were statistically different $(p<0.05)$ in the two cases considered (whole fruit and seeds). Globally, canariensis L. red date and its constitutive tissues (peel, yellow and white flesh parts) showed a greater RP and greater 2,2-Diphenyl-1picrylhydrazyl scavenging effect, compared with tissues of Phoenix dactylifera L. date palm variety. Also, a positive linear correlation of type TPC/RP $\left(R^{2}=0.983\right)$ and TPC/AA $\left(R^{2}=0.853\right)$ was observed. So, the underused Phoenix canariensis L. red date as wild fruit may be employed as natural additive in food and non-food formulations.
\end{abstract}

Keywords: Antioxidant activity; Date palm fruit; Phoenix canariensis L.; Phoenix dactylifera L.; Physical properties

\section{INTRODUCTION}

The genus Phoenix belongs to the Arecaceae family. It is composed of 14 species naturally distributed in the Old World. This genus include date palm (Phoenix dactylifera L.) widely cultivated over the world and Phoenix canariensis L. grown for ornament and religious purposes (Gros-Balthazard, 2013).

The date palm (Phoenix dactylifera L.) is believed to have been domesticated in the Mesopotamian region more than 6,000 years ago, and is among the oldest cultivated tree crops (Johnson, 2012). The fruit of this palm is a staple food of people living in arid and semi-arid regions of the world. Moreover, it plays an important role in the socioeconomic system of these regions (Haider et al., 2014).

Despite its cultivation potential in the date sector (Benziouche, 2013), Algeria does not have consequent date fruit processing technology which is exclusively limited to the production of date paste (Ghars) and packaging of the Deglet-Nour variety. In order to diversify date processing, several laboratory works, devoted for valorization of common dates like dried Mech-Degla (MD) and ornamental canariensis red date (CRD) varieties have been carried out and some summary results were communicated (Benamara et al., 2013). Among these works, the formulation of a margarine enriched with an extract of CRD peel as coloring and antioxidant agent; and the production of pharmaceutical tablets based on the date powder of MD variety, being the most promising.

Regarding Canariensis red date (CRD), there has never been any study, to our knowledge, apart from the physical and chemical characterization of its seeds and seed oil fraction performed by Nehdi et al. (2010, 2011).

Phoenix canariensis $\mathrm{L}$. palm is native to the Canary Islands and can grow on a wide variety of soils throughout the world especially in Mediterranean regions (Nehdi et al., 2011).

\footnotetext{
${ }^{*}$ Corresponding author:

Amrane Djouab, Laboratoire de Recherche Technologie Alimentaire, Faculté des Sciences de l'Ingénieur, Université M'hamed Bougara, Boumerdès 35000, Algérie. Phone: +213551100950. E-mail: amdjouab@gmail.com
} 
Thousand of these ornamental palm trees are extensively planted, these last years in Algeria, in gardens and along streets and avenues. These trees produce a large amount of fruits with astringency taste (due to its richness in tannins) which makes them non edible.

In addition, the fruits produced by this tree vary widely in physical properties (shape, length, volume, color.). Unfortunately, all these fruits end up rotting on trees and later on thrown away during the pruning. This available biomass with a great value can be valorised by recovering its bioactive molecules for further use as ingredient in food, pharmaceutical and cosmetics.

The objectives of this study were to determine the physical properties of Phoenix dactylifera L. and Phoenix canariensis L. date fruits and their seeds as well as to evaluate the antioxidant potential (AP) of the entire fruit and its different tissues. The AP of the entire fruit and its different tissues was evaluated throughout total phenolic content (TPC), reducing power (RP) and antiradicalar activity (AA) towards the stable free radical 2,2-Diphenyl1-picrylhydrazyl (DPPH). In addition, the probable synergistic effect of a mixture of MD and CRD extract as RP equivalent, in view to produce a powerful natural antioxidant, was evaluated.

\section{MATERIALS AND METHODS}

\section{Chemicals and reagents}

All the used solvents and reagents (methanol, trichloroacetic acid, potassium ferricyanide, $\mathrm{FeCl}_{3}$, gallic acid (3,4,5-trihydroxy-benzoic), Folin-Ciocalteu's phenol reagent, $\mathrm{Na}_{2} \mathrm{CO}_{3}$ and DPPH are of analytical grade and were purchased from Sigma-Aldrich, Co (Germany).

\section{Date samples}

Phoenix dactylifera L. (Mech-Degla cultivar (MD)) dates $(5 \mathrm{Kg})$ were bought at the local market of Batna $(400 \mathrm{Km}$ South east of Algiers, Algeria) (Fig. 1a), whereas the Phoenix canariensis $\mathrm{L}$. red dates (CRD) (5 Kg) Fig. 1b were collected from an ornamental date tree in the garden of the National Office of Geological and Mining Research (ORGM) in the region of Boumerdès (40 Km east of Algiers, Algeria). Fruit samples were transported to laboratory in closed polyethylene bags, washed with distilled water and then dried with clean blotting paper. The fruits were kept in an airtight plastic vessel and stored at $5{ }^{\circ} \mathrm{C}$ until use. Before starting a test, the fruits were allowed to warm up under ambient temperature $\left(22-25^{\circ} \mathrm{C}\right)$.

\section{Physical properties}

One hundred fruits of each variety were randomly selected from the $5 \mathrm{~kg}$ sample.
The three linear dimensions (Fig. 1 (a1), (a2), (b1), (b2)), namely, length (L), width (W) and thickness (T), of each of the 100 fruits/seeds were measured with a Vernier caliper with precision up to $0.01 \mathrm{~mm}$.

Mass (M) was determined on 100 randomly selected fruits/seeds. In order to determine the 1000 fruits/seeds weight $\left(\mathbb{W}_{1000}\right)$, ten sub-samples, each one consisting of 10 fruits/seeds, were randomly drawn from the bulk sample and weighed, and this weight was then extrapolated to 1000 fruits/seeds (Ixtaina et al., 2008). Fruit unit mass $(\mathrm{M})$ and 1000 fruits/ seeds weight $\left(\mathrm{W}_{1000}\right)$ were measured by using an electronic balance of $0.001 \mathrm{~g}$ sensitivity.

Some other physical parameters were determined using the procedures described in the literature: equivalent diameter $\left(D_{e}\right)$, mean diameter $\left(D_{\mathrm{g}}\right)$, sphericity $(\varnothing)$, arithmetic mean diameter $\left(\mathrm{D}_{\mathrm{a}}\right)$ and surface area (S) (Mohsenin, 1970; Mohsenin 1986), volume (V) by liquid displacement method (Aydın, 2002), volume (V) by calculation (Jain and Bal, 1997), aspect ratio $\left(R_{2}\right)$ (Omobuwajo et al., 1999), bulk density (Parrott and Thrall, 1978), porosity (Nimkar and Chattopadhyay, 2001) and angle of repose (Bart-Plange and Baryeh, 2003).

The true density of dates and seeds was calculated as follows:

$\rho_{\mathrm{f}}=\mathrm{M} / \mathrm{V}$

$\rho_{\mathrm{f}}$ is termed either real density (when $\mathrm{V}$ is determined by the liquid displacement method), or theoretical density (when $\mathrm{V}$ is determined by calculation).

The hardness and the colour (in CIELab system) were measured using texture analyzer (TA plus LLOYD instruments) and a Konica Minolta Color Reader (CR-10; Konica, Minolta Sensing INC., Japan) in the reflectance mode, respectively.

\section{Preparation of date fruit methanolic extracts}

The different tissues of dates were separated from the pulp using a house knife and then freeze-dried using a lyophilizer (CRYODOS Telstar, Terrassa, Spain). The obtained freeze-dried samples were separately ground to a fine powder using a laboratory mortar/pestle. Phenols were extracted by the method described by Tounsi et al. (2009) with a slight modification. A quantity of $1 \mathrm{~g}$ of each powder was extracted multiple times by $50 \mathrm{~mL}$ methanol for $30 \mathrm{~min}$, and the combined extracts were filtered. The obtained extract was stored at $-20{ }^{\circ} \mathrm{C}$ until analysis. TPC, RP and AA were determined on the final extract. 


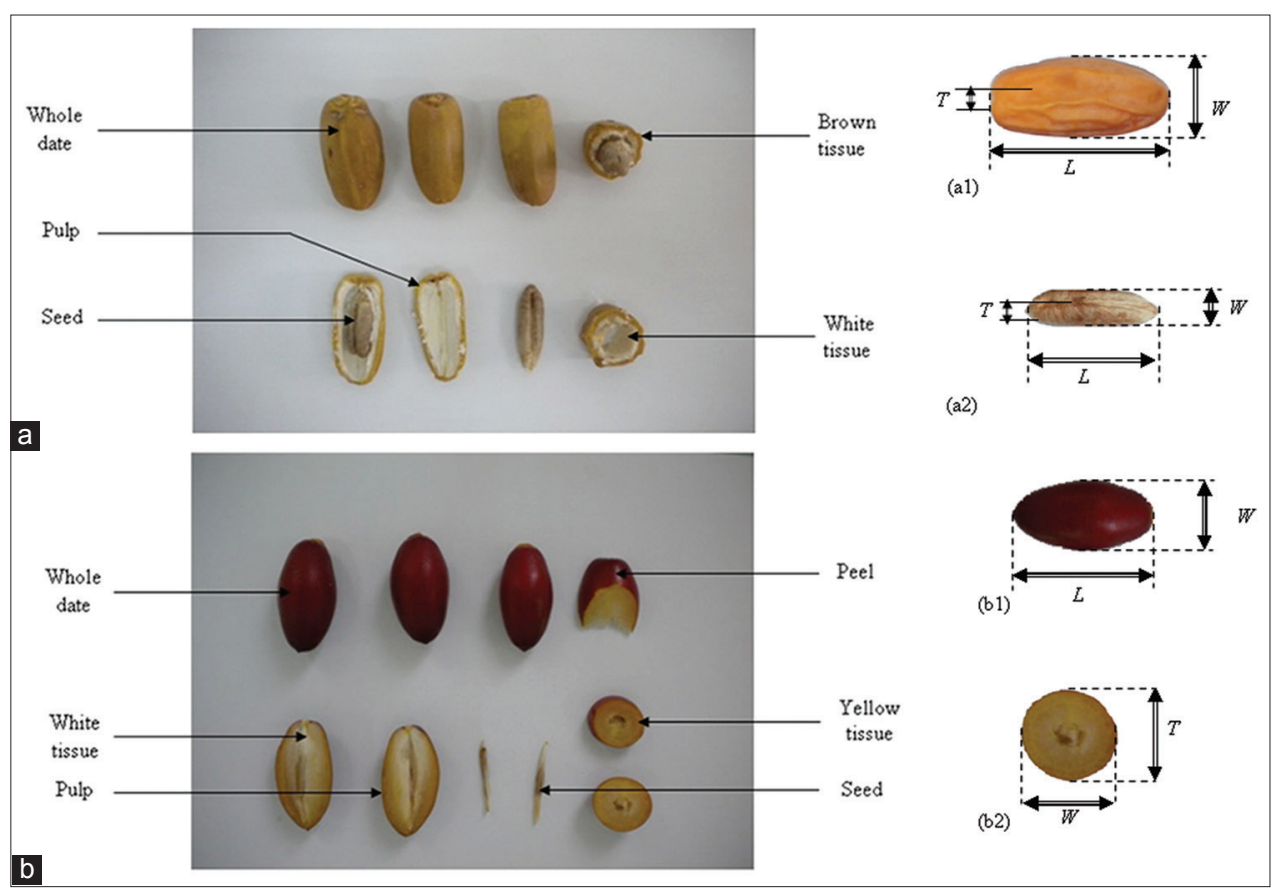

Fig 1. Phoenix dactylifera L. cv. Mech-Degla (a) and Phoenix canariensis L. red date (b) with their different constitutive parts, and their three major dimensions (a1, a2, b1 and b2).

\section{Total phenolic content (TPC)}

The TPC of MD, CRD and their respective tissues was determined by the Folin-Ciocalteu's method (Singleton et al., 1999) and the results are expressed as mg gallic acid equivalents per $100 \mathrm{~g}$ of dry matter (mg GAE/100g DM). Five hundred microlitres of the extract were mixed with $2.5 \mathrm{ml}$ Folin-Ciocalteu's reagent (diluted 10 fold) for $5 \mathrm{~min}$ and then $2 \mathrm{ml}$ of a $\mathrm{Na}_{2} \mathrm{CO}_{3}$ solution were added $(75 \mathrm{~g} / \mathrm{l})$. All samples were incubated at room temperature in dark conditions for $2 \mathrm{~h}$. after that, their absorbances were read at $760 \mathrm{~nm}$ against a blank by means of a spectrophotometer (Shimadzu UV-1800, Kyoto, Japan). The blank solution contained water instead of date extracts. For calibration curve, a stock solution of gallic acid $(1 \mathrm{mg} / \mathrm{ml})$ was prepared for further dilutions.

\section{Reducing power (RP) and synergistic effect (SE)}

The RP of the date extracts was determined according to the method of Oyaizu (1986).

Each methanolic extract $(2.5 \mathrm{ml})$ was mixed with $2.5 \mathrm{ml}$ of $0.2 \mathrm{M}$ sodium phosphate buffer ( $\mathrm{pH}$ 6.6) and $2.5 \mathrm{ml}$ of $1 \%$ potassium ferricyanide. The mixture was incubated at $50{ }^{\circ} \mathrm{C}$ for $30 \mathrm{~min}$. After $2.5 \mathrm{ml}$ of $10 \%$ trichloroacetic acid (w/v) were added, the mixture was centrifuged at $3000 \mathrm{rpm}$ for $10 \mathrm{~min}$. The upper layer $(2.5 \mathrm{ml})$ was mixed with $2.5 \mathrm{ml}$ of deionised water and $1 \mathrm{ml}$ of $0.5 \%$ of ferric chloride, and the absorbance was measured at $700 \mathrm{~nm}$ : higher absorbance indicates higher RP. Results were expressed as ascorbic acid equivalent per $100 \mathrm{~g}$ of DM (mg AAE/100g DM).
According to Liu (2003), the synergistic effect of phytochemicals in food matrix explains why no single antioxidant can replace the combination of natural phytochemicals to achieve health benefits. As is done for drugs (Yin et al. 2014), the synergistic effect (SE) was calculated in order to see whether the RP of two different extracts together is higher than the sum of the RP of each extract alone. The $S E$ was evaluated according to the formula applied by Allane and Benamara (2010):

$S E=R P_{e x p} / R P_{c a l}$

where, $R P_{\text {exp }}$ is the experimental $\mathrm{RP}$ of the binary mixture from given MD tissue extract and given CRD tissue extract, whereas the $R P_{c a l}$ is calculated as follows:

$R P_{\text {cal }}=0.5 \times\left(R P_{M D}+R P_{C R D}\right)$

Where $R P_{M D}$ and $R P_{C R D}$ are the experimental $\mathrm{RP}$ of individual $\mathrm{MD}$ and $\mathrm{CRD}$ tissue extracts, respectively, and 0.5 is the volume fraction of the given extract in the mixture. A value of $S E>1$ indicates a synergistic effect between the extracts and a value of $S E<1$ indicates an antagonistic effect. A value of $S E=1$ means neither a synergistic nor antagonistic effect.

\section{Antiradicalar activity $(A A)$ (DPPH radical scavenging activity)}

The hydrogen atoms or electrons donation ability of the corresponding extracts were measured from the 
bleaching of purple colored methanol solution of DPPH (Cuendet et al., 1997). After several trials, the following protocol was retained. $250 \mu \mathrm{l}$ of each extracts was diluted with $1.750 \mathrm{ml}$ of methanol and then mixed with $1 \mathrm{ml}$ of DPPH radical solution in methanol $(0.2$ $\mathrm{mM})$. The mixture was shaken vigorously and kept in the dark for $15 \mathrm{~min}$ at room temperature $\left(23 \pm 2{ }^{\circ} \mathrm{C}\right)$. The decrease in absorption was measured at $517 \mathrm{~nm}$ with a spectrophotometer. A control consisted of a mixture of methanol and DPPH solution without adding methanolic date extracts.

The $A A$ of the dates and their respective tissue extracts in percent was calculated by the following formula:

$A A \%=\left[\left(A_{\text {Control }}-A_{\text {Sample }}\right) / A_{\text {Control }}\right] \times 100$

where $A_{\text {Control }}$ is the absorbance of the control reaction (containing all reagents except the test extract at $t=0 \mathrm{~min}$ ), and $A_{\text {Sample }}$ is the absorbance of the tested extract solution ( $t=15 \mathrm{~min}$ ).

\section{Statistical analysis}

Results are expressed as the means $\pm \mathrm{SD}$. One-way analysis of variance (ANOVA) was used to determine the statistical difference, using XLSTAT 2008 software. Statistical significance $(\alpha)$ was 0.05 . Principal Component Analyses (PCA) and pairwise correlations were applied in order to get an overview of the main variation in the data and to interpret variable relationships. Data analyses were made using JMP 7.0 (SAS institute, Cary, NC, USA).

\section{RESULTS AND DISCUSSION}

\section{Physical properties of the whole dates}

Physical parameters of the two date varieties are summarized in Table 1. For all the analyzed parameters, a significant difference between the two varieties was observed at $p<0.05$. The parameters related to MD fruit are higher than those of CRD, except the pulp mass, sphericity and bulk density. The difference observed could be the result of the individual properties of the date varieties, as well as environmental and cultivation conditions.

Size is an important physical attribute of foods. The linear dimension of the whole dates $(\mathrm{L}, \mathrm{W}, \mathrm{T})$ of $\mathrm{MD}$ are higher than of CRD. Our results are lower than those $(\mathrm{L}=38.47$, $\mathrm{W}=24.47$ and $\mathrm{T}=23.13 \mathrm{~mm}$, and $\mathrm{L}=35.68, \mathrm{~W}=18.47$, $\mathrm{T}=17.42 \mathrm{~mm}$ ) communicated by Jahromi et al. (2008a, 2008b) for Mazafati and Dairi varieties.

Volume is known to be a parameter affecting consumer acceptance (Sahin and Sumnu, 2006). The real and theoretical volume of MD are significantly $(p<0.05)$ higher than those of CRD. In opposite to CRD, there are moreover no significant differences between the MD whole date and seeds volumes whatever the measurement method applied.

Table 1: Physical properties of Mech-Degla, canariensis red date and their seeds

\begin{tabular}{|c|c|c|c|c|c|}
\hline \multirow[t]{2}{*}{ Property } & \multirow[t]{2}{*}{$\mathbf{n}$} & \multicolumn{2}{|c|}{ Whole date fruit } & \multicolumn{2}{|c|}{ Seed } \\
\hline & & MD & CRD & MD & CRD \\
\hline Length (mm) & 100 & $36.26 \pm 2.35^{a}$ & $32.67 \pm 1.37^{b}$ & $24.68 \pm 2.25^{a}$ & $19.96 \pm 3.55^{b}$ \\
\hline Width (mm) & 100 & $18.38 \pm 2.86^{a}$ & $16.78 \pm 1.59^{b}$ & $7.84 \pm 0.70^{\mathrm{a}}$ & $2.75 \pm 0.01^{b}$ \\
\hline Thickness (mm) & 100 & $16.51 \pm 2.56^{a}$ & $15.64 \pm 1.02^{b}$ & $6.58 \pm 0.73^{a}$ & $1.77 \pm 0.29^{b}$ \\
\hline Mass $(g)$ & 100 & $6.12 \pm 0.84^{a}$ & $4.61 \pm 0.61^{b}$ & $0.98 \pm 0.22^{\mathrm{a}}$ & $0.04 \pm 0.02^{b}$ \\
\hline Mass pulp (g) & 100 & $5.19 \pm 0.76^{a}$ & $4.54 \pm 0.71^{b}$ & N/A & $\mathrm{N} / \mathrm{A}$ \\
\hline Thousand weight $\left(\mathrm{W}_{1000}\right)(\mathrm{g})$ & 10 & $5236.5 \pm 408.64^{\mathrm{a}}$ & $4791.2 \pm 132.61^{b}$ & $1051.1 \pm 58.35$ & $\mathrm{~N} / \mathrm{A}$ \\
\hline Equivalent diameter $\left(\mathrm{D}_{\mathrm{e}}\right)(\mathrm{mm})$ & 100 & $22.22 \pm 2.123^{a}$ & $20.46 \pm 1.12^{b}$ & $10.85 \pm 0.89^{a}$ & $4.63 \pm 0.82^{b}$ \\
\hline Geometric mean diameter ( $\mathrm{D} \mathrm{mm})$ & 100 & $22.16 \pm 2.10^{\mathrm{a}}$ & $20.45 \pm 1.10^{b}$ & $10.82 \pm 0.90^{a}$ & $4.55 \pm 0.70^{b}$ \\
\hline Arithmetic mean diameter $\left(\mathrm{D}_{\mathrm{a}}^{\mathrm{g}} \mathrm{mm}\right)$ & 100 & $23.72 \pm 1.87^{a}$ & $21.70 \pm 1.05^{b}$ & $13.03 \pm 1.01^{\mathrm{a}}$ & $8.20 \pm 1.31^{b}$ \\
\hline Volume $\left(\mathrm{cm}^{3}\right)$ (Real) & 100 & $5.94 \pm 0.80^{\mathrm{a} *}$ & $4.89 \pm 0.63^{b *}$ & $0.73 \pm 0.15^{*}$ & N/A \\
\hline Volume $\left(\mathrm{cm}^{3}\right)$ (theoretical) & 100 & $5.91 \pm 1.99^{a \star}$ & $4.53 \pm 0.79^{b \star *}$ & $0.68 \pm 0.14^{a *}$ & $0.05 \pm 0.016^{b}$ \\
\hline Sphericity & 100 & $0.61 \pm 0.06^{a}$ & $0.63 \pm 0.03^{b}$ & $0.44 \pm 0.04^{a}$ & $0.24 \pm 0.08^{b}$ \\
\hline Aspect ratio $\left(R_{a}\right)$ & 100 & $0.51 \pm 0.08^{a}$ & $0.51 \pm 0.05 a$ & $0.32 \pm 0.04^{a}$ & $0.15 \pm 0.10^{b}$ \\
\hline Surface area $\left(\mathrm{mm}^{2}\right)$ & 100 & $1557.22 \pm 310.68^{a}$ & $1317.29 \pm 144.19^{b}$ & $370.22 \pm 54.26^{a}$ & $66.46 \pm 21.06^{b}$ \\
\hline Density (g/cm³) (Real) & 100 & $1.03 \pm 0.06^{a^{\star}}$ & $0.94 \pm 0.04^{\mathrm{b} *}$ & $1.34 \pm 0.22^{*}$ & N/A \\
\hline Density $\left(\mathrm{g} / \mathrm{cm}^{3}\right)$ ( theoretical) & 100 & $1.11 \pm 0.50^{\mathrm{a} *}$ & $1.03 \pm 0.07^{a \star *}$ & $1.44 \pm 0.25^{a \star \star}$ & $0.79 \pm 0.16^{b}$ \\
\hline Bulk density $\left(\mathrm{g} / \mathrm{cm}^{3}\right)$ & 10 & $0.59 \pm 0.01^{\mathrm{a}}$ & $0.61 \pm 0.01^{\mathrm{b}}$ & $0.69 \pm 0.02$ & $\mathrm{~N} / \mathrm{A}$ \\
\hline Porosity (\%) & 10 & $43.31 \pm 1.23^{a}$ & $34.80 \pm 0.67^{b}$ & $48.40 \pm 1.42$ & $\mathrm{~N} / \mathrm{A}$ \\
\hline Angle of repose (deg.) & 10 & $29.1 \pm 2.31^{\mathrm{a}}$ & $20.10 \pm 1.20^{\mathrm{b}}$ & $17.6 \pm 2.12$ & $\mathrm{~N} / \mathrm{A}$ \\
\hline Hardness (N) & 10 & $27.46 \pm 7.45^{a}$ & $12.98 \pm 3.00^{b}$ & $\mathrm{~N} / \mathrm{A}$ & $\mathrm{N} / \mathrm{A}$ \\
\hline \multicolumn{6}{|l|}{ Colour properties } \\
\hline$L^{*}$ & 3 & $57.27 \pm 0.31^{a}$ & $31.80 \pm 0.85^{b}$ & $\mathrm{~N} / \mathrm{A}$ & $\mathrm{N} / \mathrm{A}$ \\
\hline$a^{*}$ & 3 & $16.13 \pm 0.93^{a}$ & $37.80 \pm 1.53^{b}$ & $\mathrm{~N} / \mathrm{A}$ & $\mathrm{N} / \mathrm{A}$ \\
\hline$b^{*}$ & 3 & $38.17 \pm 0.80^{a}$ & $10.20 \pm 0.46^{b}$ & $\mathrm{~N} / \mathrm{A}$ & $\mathrm{N} / \mathrm{A}$ \\
\hline
\end{tabular}

MD: Mech-Degla (Phoenix dactylifera L.); CRD: Phoenix canariensis red date. ${ }^{*}$ Non significant difference and ${ }^{* *}$ Significant difference at $p<0.05$ in the same column for whole dates or seeds; $n$ : Number of samples. Data are mean values \pm standard deviation. Mean value within the same line having the same letter are not significantly different at $p<0.05$ 
The bulk density of fruit is a useful tool in the design of silos and storage bins (Varnamkhasti et al., 2008). Since the bulk density of the MD variety is less than that of the CRD variety, the latter would require a larger silo compared to MD variety with the same weight.

The MD porosity is higher than the CRD's. This indicates that aeration of the bulk of MD is easier than the one of the CRD fruits, displaying thus favourable implications for all processes needing high contact surfaces, since the porosity shows the extent of pore space in the biological material mass (Ilori et al., 2011). Our results ranged in the interval (30-60\%) globally revealed by Demir and Kalyoncu (2003) for cornelian cherry (Cornus mas L.) whose geometric form and colour recall remarkably the CRD.

The 1000 fruit weight, angle of repose and hardness of MD are higher than those of CRD. The obvious smooth surface and roundness of the CRD, compared to MD dates, is apparently responsible for the relatively lower values of the angle of repose. Subsequently, the fruit presents an easiness to slide on each other.

MD is 2 times harder than CRD. We think that this dissimilarity is due to the presence of a hard seed in MD. Ben Ismail et al. (2013) found the firmness of 17 Tunisian date varieties with seeds between 1.4 and $5.9 \mathrm{Kg}$, while the fruits without seed ranged between 1.1 to $5.2 \mathrm{Kg}$. Although it is impossible to compare the results found with our results the authors conclude that the dry date (Kentichi) has the great value and the soft (Tezerzit Safra) the lower.

The appearance of fruit products plays an important role in determining consumer acceptance (Francis and Clydesdale, 1975). Table 1 presents the CIE Lab values ( $\left.L^{*}, a^{*}, b^{*}\right)$ of $\mathrm{MD}$ and CRD dates. The two investigated varieties show a significant difference $(\phi<0.05)$ in the colour parameters, the CRD being particularly redder. Our results are globally higher than those ( $\left.L^{*}: 24.5-51.1, a^{*}: 2.4-17.6, b^{*}: 1.7-36.6\right)$ communicated by Ben Ismail et al. (2013) concerning 17 Tunisian date varieties. In particular, CRD presents a higher $a^{*}$ value than other common fruits, generally named red fruits: strawberries: 28 (Crecente-Campo et al., 2012), orange: 37 (Topuz et al., 2005), tomatoes: $\sim 25$ (Liu et al., 2009) and cornelian cherry: (16.88-24.72) (Nalbandi et al., 2001). In terms of $a^{*} / b^{*}$ ratio, expressing at the same time the redness (Min and Zhang, 2003) and anthocyanin content (Ercisli et al., 2011), the value found presently (3.70) is higher than those exhibited by cornelian cherry (1.44-2.70) (Ercisli et al., 2011), strawberry juice (2.8-3.0) (Aguiló-Aguayo et al., 2009). The fruit peel colour may be linked with the Brix as that has been demonstrated by Khandaker et al. (2012) for the red wax apple (Syrygium samarangense) fruits. For us, this intense colour is practically
Table 2: Total phenol content and antioxidant potential of different date fruit tissues

\begin{tabular}{lcccc}
\hline Sample & $\mathbf{n}$ & $\begin{array}{c}\text { Total phenolic } \\
(\mathrm{GAE} / 100 \mathrm{~g} \text { DM) }\end{array}$ & $\begin{array}{c}\text { Reducing power } \\
(\mathrm{mg} \mathrm{AAE} / 100 \mathrm{~g} \text { DM) }\end{array}$ & $\begin{array}{c}\text { DPPH assay } \\
(\%)\end{array}$ \\
\hline MD & 3 & $206.24 \pm 0.35^{\mathrm{c}, \mathrm{d}}$ & $431.12 \pm 35.55^{\mathrm{c}}$ & $52.89 \pm 0.60^{\mathrm{b}, \mathrm{c}}$ \\
PMD & 3 & $247.33 \pm 22.05^{\mathrm{c}, \mathrm{d}}$ & $342.64 \pm 71.09^{\mathrm{c}}$ & $61.21 \pm 5.98^{\mathrm{b}}$ \\
BTMD & 3 & $185.20 \pm 27.30^{\mathrm{c}, \mathrm{d}}$ & $281.31 \pm 56.87^{\mathrm{c}}$ & $44.78 \pm 11.47^{\mathrm{c}}$ \\
WTMD & 3 & $66.63 \pm 14.35^{\mathrm{d}}$ & $187.81 \pm 12.80^{\mathrm{c}}$ & $12.69 \pm 1.40^{\mathrm{d}}$ \\
CRD & 3 & $2600.50 \pm 110.27^{\mathrm{a}}$ & $2527.60 \pm 327.03^{\mathrm{a}}$ & $94.41 \pm 0.16^{\mathrm{a}}$ \\
PCRD & 3 & $1525 \pm 31.50^{\mathrm{b}}$ & $1994.73 \pm 28.44^{\mathrm{b}}$ & $91.82 \pm 0.60^{\mathrm{a}}$ \\
YTCRD & 3 & $1698.27 \pm 182.03^{\mathrm{b}}$ & $2228.49 \pm 53.32^{\mathrm{a}, \mathrm{b}}$ & $94.22 \pm 0.9^{\mathrm{a}}$ \\
WTCRD & 3 & $315.40 \pm 17.50^{\mathrm{c}}$ & $461.28 \pm 48.34^{\mathrm{c}}$ & $58.60 \pm 7.48^{\mathrm{b}}$ \\
\hline
\end{tabular}

MD, PMD, BTMD and WTMD=Mech-Degla (Phoenix dactylifera L.) whole flesh, peel, brown tissue, and white tissue, respectively. CRD, PCRD, YTCRD, WTCRD=Phoenix canariensis $\mathrm{L}$. red date whole flesh, peel, yellow tissue, and white tissue, respectively. n: Number of samples. DM: Dry matter. Data are mean \pm standard deviation. Mean value within the same column having the same letter are not significantly different at $p<0.05$

the unique quality criterion which raises our interest in valorization of this date fruit.

Regarding all parameters studied currently, MD seeds show the highest values, compared to CRD $(p<0.05)$ (see Table 1). Moreover, the great mass of CRD which is twenty-five fold lower than that of MD must be noticed.

\section{Antioxidant potential (AP) of MD and CRD Total phenolic content (TPC)}

The TPC of MD, CRD and their different tissues ranged between 66.63 and $2600.5 \mathrm{mg}$ of GAE/100 $\mathrm{g} \mathrm{DM}$ (Table 2). The order of the TPC was as follows: CRD $>$ YTCRD $>$ PCRD $>$ WTCRD $>$ PMD $>$ MD $>$ BTMD $>$ WTMD. From the results, it is clear that the CRD pulp and their different tissues have the highest content than that of MD and their tissues. Also, the WT is the poorest in terms of TPC compared to the other tissues.

The TPC of MD and their different tissues are higher than those of other Algerian dates reported in the literature: 2.49 - $8.36 \mathrm{mg}$ GAE/100 $\mathrm{g}$ fresh weight (FW) (Mansouri et al., 2005) and 41.8-84.73 mg GAE/100 g (DM) (Zineb et al., 2012). In addition, our values are greater to those (2.89-141.35 DM) communicated by Biglari et al. (2009) about Iranian varieties. These observed differences can be explained by diverse factors such as variety, growing and experimental conditions.

No data is available in the literature concerning the AP of Phoenix canariensis L. date fruit. From Table 2 it can be noticed that the TPC of CRD is about 13 -fold higher than that of MD. In comparison with other fruits species, the TPC of CRD flesh is higher than those (11.88-585.52 mg GAE/100 g DM) of Chinese common fruits (Fu et al., 2011).

Based on these finding, it is clear that phenolic substances were located in the peel and yellow/brown tissues. This 
observation is supported by Guo et al. (2003) regarding 28 Chinese common fruits, including date, orange and cherry and Arazo et al. (2011) on yellow mangosteen fruits.

\section{Reducing power (RP) and synergistic effect (SE)}

The RP of MD, CRD and their different tissue (Table 2) gives the following classification: $\mathrm{CRD}>\mathrm{YTCRD}>\mathrm{PCRD}>$

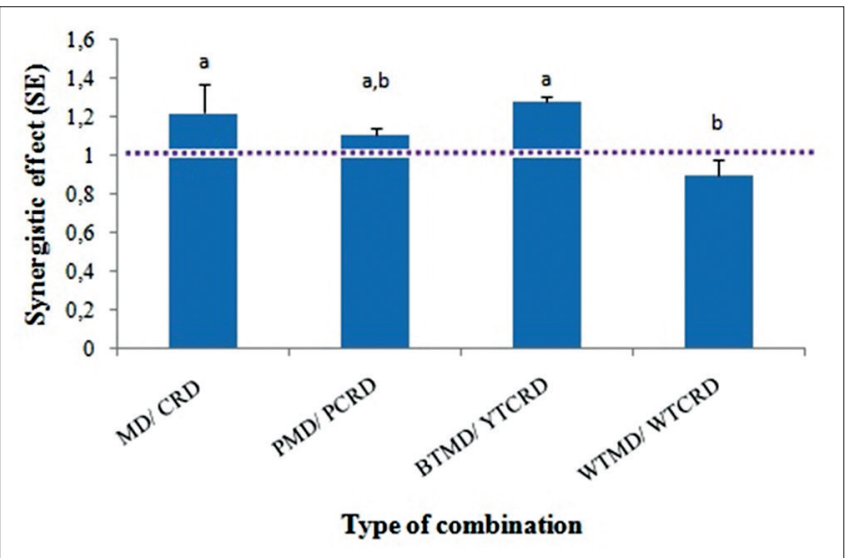

Fig 2. Synergistic effect between different Mech-Degla (MD) and Canariensis red dates (CRD) tissue extracts on reducing power (RP) value. MD, PMD, BTMD and WTMD = Mech-Degla (Phoenix dactylifera L.) whole flesh, peel, brown tissue, and white tissue, respectively. CRD, PCRD, YTCRD, WTCRD = Phoenix canariensis $\mathrm{L}$. red date whole flesh, peel, yellow tissue, and white tissue, respectively.

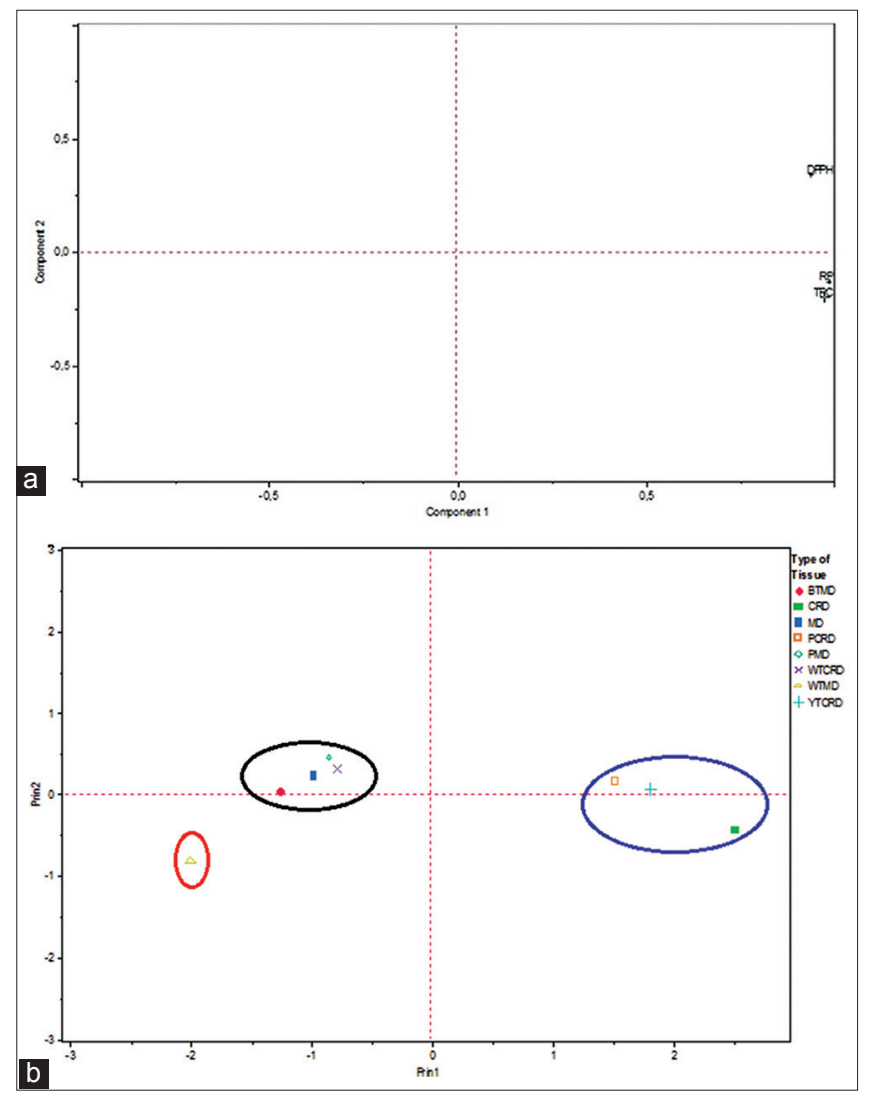

Fig 3. Graph of loading plot (a) of AP and scores plot of principal component (b) of MD, CRD and their different tissues.
WTCRD $>$ MD $>$ PMD $>$ BTMD $>$ WTMD. The RP value of the whole flesh of CRD is $\sim 6$-fold higher than that of MD. This result is confirmed by the highest phenol content of CRD. The RP of CRD (2527.60 mg AAE/100g) is higher than those (500 to $2049 \mathrm{mg}$ AAE/100g of FW and 210 to $681 \mathrm{mg} \mathrm{AAE} / 100 \mathrm{~g}$ of DM) found by Allane and Benamara (2010) for 27 Algerian common fruits, and Ouchemoukh et al. (2012) concerning different wild and dried fruits, respectively. Using phosphomolybdenum method for AA quantification, Kchaou et al. (2013) obtained an AA of 77.47-105.45 and 89.55-109.67 mg $\mathrm{AAE} / \mathrm{g}$ FW for Tunisian date varieties.

In view to improve the antioxidant potential of MD extract which is destined as additive in enriched margarines, the study of the probable synergistic effect of a mixture of $\mathrm{MD}$ and CRD extract was investigated. The synergistic effect in terms of RP value of the mixture (1:1 ratio) of $\mathrm{MD}$ and CRD (whole flesh and constitutive tissues) are illustrated in the Fig. 2. The results gave the following ordering: BTMD/YTCRD > MD/CRD > PMD/PCRD> WTMD/WTCRD. So, apart from the WTMD/WTCRD mixture for which the antagonistic effect was observed $(\mathrm{SE}<1)$, all other combinations show a good synergistic effect (SE $>1)$. Allane and Benamara (2010) found a SE (1.29-2.24) for several fruit peel combinations.

\section{Antiradicalar activity (AA) (DPPH radical scavenging activity)}

The DPPH assay is commonly used for determination of free radical scavenging activity of antioxidant. DPPH is a very stable organic free radical and presents the ability of accepting an electron or hydrogen radical.

The AA, quantified by means of DPPH radical scavenging activity of MD, CRD and their different tissue (Table 2) shows the following arrangement: CRD $>$ YTCRD $>$ PCRD $>$ PMD $>$ WTCRD $>$ MD $>$ BTMD $>$ WTMD. In particular, the high radical scavenging of CRD must be noticed since it is $\sim 1.8$-fold higher than MD.

Concerning CRD fruit and their tissues the obtained results in terms of DPPH assay are close to the values (57.54-90.12\%) reported by Kchaou et al. (2013) about Tunisian date varieties by using both acetone $/ \mathrm{H}_{2} \mathrm{O}$

Table 3: Correlation analysis results of MD, CRD and their Constitutive tissues for different antioxidant assays

\begin{tabular}{lccc}
\hline & TPC & $\begin{array}{r}\text { DPPH } \\
\text { assay }\end{array}$ & RP \\
\hline TPC & 1.000 & 0.853 & 0.983 \\
DPPH & 0.853 & 1.000 & 0.883 \\
RP & 0.983 & 0.883 & 1.000 \\
\hline
\end{tabular}

TPC: Total phenolic content, DPPH assay: Antiradicalar activity, RP: Reducing power 
and methanol $/ \mathrm{H}_{2} \mathrm{O}$ as extraction solvents. Whereas, Benmeddour et al. (2013), working on ten Algerian date palm varieties, obtained an average DPPH scavenging capacity (32- 86\%) sensibly lower than our values.

Comparing with other dried common fruit consumed in Algeria, Ouchemoukh et al. (2012), report the maximum value (in \%) of: 1) 87.7 (Agen prune), 87.0 (prune), 63.3 (apricots), using methanol/water $(1: 1, \mathrm{v} / \mathrm{v})$, and 2$)$ 92.2 (raisin) and 55.9 (figs) using ethanol/water $(1: 1, \mathrm{v} / \mathrm{v})$ as solvent. From these data, it becomes clear that MD, as dried fruit specie, is relatively less rich in antioxidant substances.

\section{Correlation studies between the TPC and total AP}

It is important to study the correlation between the TPC, and total AP. Some authors reported that there is no correlation between TPC and total, whereas others found the opposite (Moure et al., 2001). Presently, a high positive linear correlation between the TPC and total AP (RP: $R^{2}=0.983$, DPPH assay: $R^{2}=0.853$ ) was observed as shown in Table 3, respectively $(p<0.05)$. This result indicates that phenolics components contribute substantially, in case of TPC/RP in particular, to the AP of date fruit. Sanda et al. (2015) found a positive correlation between TPC/DPPH scavenging activity $\left(R^{2}=0.811\right)$ and TPC $/ R P\left(R^{2}=0.707\right)$ of two Daphne species from Turkey. Also, Abbès et al. (2013) observed a presence of correlation between the AA and TPC of date syrup. The loading of first and second principle components (PC1 and PC2) of the TPC and AP are $93.79 \%$ and $5.75 \%$ of the variance, respectively (Fig. 3a). The score plot (Fig. 3b) segregates three groups between the studied samples. Indeed, the first group (CRD, PCRD and YTCRD) are the richest on TPC and the highest on AP, the second group (PMD, MD, BTMD and WTCRD) are less rich on TPC and have a average AP while WTMD is distinguished with his poverty on TPC and a weakness on AP.

\section{CONCLUSION}

From results, it can be deduced that $\mathrm{MD}$ and $\mathrm{CRD}$ date varieties as well as their seeds are statistically different $(p<0.05)$ on major physical properties such as linear dimensions, angle of repose and hardness. Globally, CRD and its constitutive tissues (peel, yellow and white flesh parts) showed a greater antioxidant activity in terms of $\mathrm{RP}$ and AA (DPPH assay), compared with the MD variety. Also, a positive linear correlation between antioxidant power and phenolic content was observed $\left(R^{2}=0.983\right.$ in case of RP). Finally, the synergistic effect between MD and CRD tissue extracts, in term of RP, are almost always $>1$. So, the underused Phoenix canariensis L. red date as wild fruit may be employed as natural additive in food and nonfood formulations.

\section{ACKNOWLEDGMENTS}

The authors wish to thanks Mr Aïssa Boukhiar and Boualem Chennit for statistical analysis. Also, a great thanks to Farid Chebrouk and Malek Bensalah Eddine for English revision.

\section{Author contributions}

A.D: Designed the study, did the analysis and wrote the article. S.B: Was involved in overall planning, supervision and critical revision. H.G: Proposal of the research topic, it's planning and supervision. H.A and K.H: Participate on carrying out experiments.

\section{REFERENCES}

Abbès, F., S. Besbes, B. Brahim, W. Kchaou, H. Attia and C. Blecker. 2013. Effect of concentration temperature on some bioactive compounds and antioxidant properties of date syrup. Food Sci. Technol. Int. 19: 323-333.

Aguiló-Aguayo, I., G. Oms-Oliu, R. Soliva-Fortuny and O. MartınBelloso. 2009. Changes in quality attributes throughout storage of strawberry juice processed by high-intensity pulsed electric fields or heat treatments. LWT - Food. Sci. Technol. 42: 813-818.

Allane, T. and S. Benamara. 2010. Activités antioxydantes de quelques fruits communs et sauvages d'algerie. Phytothérapie. 8: 171-175.

Arazo, M., A. Bello, L. Rastrelli, M. Montelier, L. Delgado and C. Panfet. 2011. Antioxidant properties of pulp and peel of yellow mangosteen fruits. Emirates J. Food Agric. 23: 517-524.

Aydın, C. 2002. Physical properties of hazel nuts. Biosyst. Eng. 82: 297-303.

Bart-Plange, A. and E. A. Baryeh. 2003. The physical properties of category B cocoa beans. J. Food Eng. 60: 219-227.

Ben Ismaïl, H., N. Djendoubi, A. Kodia, D. Ben Hassine and M. Ben Slama. 2013. Physicochemical characterization and sensory profile of 7 principal Tunisian date cultivars. Emirates J. Food Agric. 25: 331-341.

Benamara, S., A. Boukhiar, A. Djouab, T. Aksil, T. Allane, N. Iguergaziz, D. Megdoud, S. Babouri, M. Bouda, R. Djenhia, K. Kechadi, S. Letrache, W. Nakib, F. Ouamrane, K. Ressioui and S. Sekkak. 2013. New functional food formulations from Algerian agroressources. The 16th Annual Vitafoods Europe Conference, Palexpo, Geneva, Switzerland, 14-16 May, 2013.

Benmeddour, Z., E. Mehinagic, D. Le Meurlay and H. Louaileche. 2013. Phenolic composition and antioxidant capacities of ten Algerian date (Phoenix dactylifera L.) cultivars: A comparative study. J. Funct. Foods. 5: 346-354.

Benziouche, S. E. 2013. The sector of dates in Algeria, role in national economy and position on the international market. Acta Hortic. (ISHS). 994: 155-162.

Biglari, F., A. F. M. AlKarkhi and A. M. Easa. 2008. Antioxidant activity and phenolic content of various date palm (Phoenix dactylifera) fruits from Iran. Food Chem. 107: 1636-1641.

Crecente-Campo, J., M. Nunes-Damaceno, M. A. Romero-Rodríguez and M. L. Vázquez-Odériz. 2012. Color, anthocyanin pigment, ascorbic acid and total phenolic compound determination in organic versus conventional strawberries (Fragaria $\times$ ananassa Duch, cv Selva). J. Food Compos. Anal. 28: 23-30. 
Cuendet, M., K. Hostettmann and O. Potterat. 1997. Iridoid glucosides with free radical scavenging properties from Fagraea blumei. Helv. Chim. Acta. 80: 1144-1152.

Demir, F. and I. H. Kalyoncu. 2003. Some nutritional, pomological and physical properties of cornelian cherry (Cornus mas L.). J. Food Eng. 60: 335-341.

Ercisli, S., S. O. Yilmaz, J. Gadze, A. Dzubur, S. Hadziabulic and J. Aliman. 2011. Some fruit characteristics of cornelian cherries (Cornus mas L.). Not. Bot. Hortic. Agrobo. 39: 255-259.

Francis, F. J. and F. M. Clydesdale. 1975. Food Colorimetry: Theory and Applications, AVI Publishing Company, Inc., Westport, CT, USA.

Fu, L., B. T. Xu, X. R. Xu, R. Y. Gan, Y. Zhang, E. Q. Xia and H. B. Li. 2011. Antioxidant capacities and total phenolic contents of 62 fruits. Food Chem. 129: 345-350.

Gros-Balthazard, M. 2013. Hybridization in the genus Phoenix: A review. Emirates J. Food Agric. 25: 831-842.

Guo, C., J. Yang, J. Wei, Y. Li, J. Xu and Y. Jiang. 2003. Antioxidant activities of peel, pulp, and seed fractions of common fruits as determined by FRAP assay. Nutr. Res. 23: 1719-1726.

Haider, M. S., I. A. Khan, M. J. Jaskani, S. A. Naqvi and M. M. Khan. 2014. Biochemical attributes of dates at three maturation stages. Emirates J. Food Agric. 26: 953-962.

Ilori, T. A., O. B. Oradugba and A. O. Raji. 2011. Physical properties of Mexican sunflower seed. Int. Agrophys. 25: 299-302.

Ixtaina, V. Y., S. M. Nolasco and M. C. Tomás. 2008. Physical properties of chia (Salvia hispanica L.) seeds. Ind. Crop Prod. 28: 286-293.

Jahromi, M. K., S. Rafiee, A. Jafari, M. R. G. Bousejin, R. Mirasheh and S. S. Mohtasebi. 2008b. Some physical properties of date fruit (cv. Dairi). Int. Agrophys. 22: 221-224.

Jahromi, M. K., S. S. Mohtasebi, A. Jafari, R. Mirasheh and S. Rafiee. 2008a. Determination of some physical properties of date fruit (cv. Mazafati). J. Agric. Technol. 4: 1-9.

Jain, R. K. and S. Bal. 1997. Properties of pearl millet. J. Agric. Eng. Res. 66: 85-91.

Johnson, D. V. 2012. Enhancement of date palm as a source of multiple products: Examples from other industrialized palms. Emirates J. Food Agric. 24: 408-414.

Kchaou, W., F. Abbès, C. Blecker, H. Attia and S. Besbes. 2013. Effects of extraction solvents on phenolic contents and antioxidant activities of Tunisian date varieties (Phoenix dactylifera L.). Ind. Crop Prod. 45: 262-269.

Khandaker, M. M., N. Osman, A. S. Hossain and A. N. Boyce. 2012. Effects of the phloemic stress on the growth, development and quality of wax apple (Syzygium samarangense) Cv. Jambu madu. Sains Malays. 41: 553-560.

Liu, L. H., D. Zabaras, L. E. Bennett, P. Aguas and B. W. Woonton. 2009. Effects of UV-C, red light and sun light on the carotenoid content and physical qualities of tomatoes during post-harvest storage. Food Chem. 115: 495-500.

Liu, R. H. 2003. Health benefits of fruits and vegetables are from additive and synergistic combination of phytochemicals. Am. J Clin. Nutr. 78: 517S-520S.

Mansouri, A., G. Embarek, E. Kokkalou and P. Kefalas. 2005. Phenolic profile and antioxidant activity of the Algerian ripe date palm fruit (Phoenix dactylifera). Food Chem. 89: 411-420.

Min, S. and Q. H. Zhang. 2003. Effects of commercial-scale pulsed electric field processing on flavor and color of tomato juice. J. Food Sci. 68: 1600-1606.
Mohsenin, N. N. 1970. Physical properties of plant and animal materials. Physical Characteristics and Mechanical Properties, Vol. 1. Gordon and Breach, New York.

Mohsenin, N. N. 1986. Physical Properties of Plant and Animal Materials, 2nd ed. Gordon and Breach Science Publishers, New York.

Moure, A., J. M. Cruz, D. Franco, J. M. Domínguez, J. Sineiro, H. Domínguez, M. J. Núnñez and J. C. Parajó. 2001. Natural antioxidants from residual sources. Food Chem. 72: 145-171.

Nalbandi, H., S. Seiiedlou, J. Hajilou, M. Moghaddam and M. Adlipour. 2011. Physical properties and color characteristics of Iranian genotypes of cornelian cherry. J. Food Process Eng. 34: 792-803.

Nehdi, I. A., H. Zarrouk and S. I. Al-Resayes. 2011. Changes in chemical composition of Phoenix canariensis Hort. Ex Chabaud palm seed oil during the ripening process. Sci. Hortic. 129: $724-729$.

Nehdi, I, S. Omri, M. I. Khalil and S. I. Al-Resayes. 2010. Characteristics and chemical composition of date palm (Phoenix canariensis) seeds and seed oil. Ind Crops Prod. 32: 360-365

Nimkar, M. P. and K. P. Chattopadhyay. 2001. Some physical properties of green gram. J. Agric. Eng. Res. 80: 183-189.

Omobuwajo, T. O., A. E. Akande and L. A. Sanni. 1999. Selected physical, mechanical and aerodynamic properties African Breadfruit (Treculia africana) seeds. J. Food Eng. 40: 241-244.

Ouchemoukh, S., S. Hachoud, H. Boudraham, A. Mokrani and H. Louaileche. 2012. Antioxidant activities of some dried fruits consumed in Algeria. LWT - Food. Sci. Technol. 49: 329-332.

Oyaizu, M. 1986. Studies on products of browning reaction: antioxidative activity of products of browning reaction. Jpn. J. Nutr. 44: 307-315.

Parrott, M. E. and B. E. Thrall. 1978. Functional properties of various fibers: Physical properties. J. Food Sci. 43: 759-763.

Sahin, S. and S. G. Sumnu. 2006. Physical Properties of Food. Ed Springer Science + Business Media, LLC, Boston, p. 257.

Sanda, M. A., G. Zengin, A. Aktumsek and Y. S. Cakmak. 2015 Evaluation of antioxidant potential of two Daphnespecies ( $D$. Gnidioides and $D$. Pontica) from Turkey. Emirates J. Food Agric. 27: 488-494.

Singleton, V. L., R. Orthofer and R. M. Lamuela-Raventos. 1999. Analysis of total phenols and other oxidation substrates and antioxidants by means of folin-ciocalteu reagent. Method Enzymol. 299: 152-178.

Topuz, A., M. Topakci, M. Canakci, I. Akinci and F. Ozdemir. 2005. Physical and nutritional properties of four orange varieties. J. Food Eng. 66: 519-523.

Tounsi, M. S., I. Ouerghemmi, W. A. Wannes, R. Ksouri, H. Zemni, B. Marzouk and M. E. Kchouk. 2009. Valorization of three varieties of grape. Ind. Crop Prod. 30: 292-296.

Varnamkhasti, M. G., H. Mobli, A. Jafari, A. R. Keyhani, S. H. Soltanabadi, S. Rafiee and K. Kheiralipour. 2008. Some physical properties of rough rice (Oryza Sativa L.) grain. J. Cereal Sci. 47: 496-501.

Yin, N., W. Ma, J. Pei, Q. Ouyang, C. Tang and L. Lai. 2014. Synergistic and antagonistic drug combinations depend on network topology. PLoS One. 7: e93960, 1-7.

Zineb, G., M. Boukouada, A. Djeridane, M. Saidi and M. Yousfi. 2012. Screening of antioxidant activity and phenolic compounds of various date palm (Phoenix dactylifera) fruits from Algeria. Med. J. Nutr. Metab. 5: 119-126. 